TORSTI HYYRYLÄINEN

HT, dosentti, tutkimusjohtaja

Helsingin yliopisto

Ruralia-instituutti

\title{
Omakohtaisesti maaseudun muutoksesta
}

\author{
Silja Keränen: Missä syrjä sijaitsee? Kun kaupunki ei ole \\ kaikki. 2021. Kirjapaja. Helsinki. 192 s.
}

DOI: https://doi.org/10.51807/maaseutututkimus.112223

\begin{abstract}
7 Tissä syrjä sijaitsee? on kokoelma aiheita ja kysymyksiä, jotka ovat todennäköisesti risteilleet monien mielessä aikana, jolloin kansainvälinen pandemia on pakottanut meidät etsimään uusia näkökulmia omaan elämään, työhön ja ajatuksiin. Silja Keräsen teos on nähtävissä osana laajempaa keskustelua, jossa uutta normaalia jäsennetään omakohtaisesti uuteen asentoon.
\end{abstract}

Keränen on tehnyt taustatyötä ja kerännyt kunnioitettavan määrän ajankohtaista keskustelua ja terminologiaa yhteen. Alkuna on hyvinvointivaltion "luomiskertomus". Sen kautta hahmottuu isompi ja monitahoisempi kokonaiskuva, jossa on useita ytimiä ja syrjiä. Julkista keskustelua seuraava lukija tunnistaa tekstissä tuttuja termejä, kuten älykäs sopeutuminen, tietotyö, vihreä siirtymä, kaksoiskuntalaisuus, monipaikkaisuus, ekologisuus ja kuntien elinvoima.

Kirjoittaja ohjaa lukijaa kiinnostavien otsikoiden kautta isoihin ja vaikeisiin kysymyksiin. Tekstissä risteytetään runsasta lähdeaineistoa omakohtaiseen tulkintaan. Tuloksena on sisällöltään moninainen mutta toisaalta yksityiskohdissaan hajautuva kokonaisuus. Aiheeseen vihkiytynyt lukija kyllä pysyy mukana, mutta matkan edetessä juoni hämärtyy: mitä kirjoittaja lopulta haluaa sanoa? Teoksen voi toki tulkita hyvinvointiyhteiskunnan, ympäristön ja maaseudun maltilliseksi puolustuspuheeksi. Vastakkainasettelua kaupungin ja maaseudun välille kirjoittaja ei halua luoda. Kaupunki ei - tietenkään - ole kaikki. 
Keränen nostaa rohkeasti esiin näkemyksiään. Konkretiaakin löytyy, esimerkkinä ehdotus kaksoiskuntalaisuusneuvostoista, jotka olisivat "kaksoiskuntalaisten" edustajistoja paikkakunnilla. Hänen mukaansa ne toisivat kunnille tilaisuuden ajatella ja toimia uudistavasti ja verkottuneesti elinvoiman puolesta. Ehdotus on ajankohtainen esimerkki pyrkimyksestä etsiä ratkaisuja liikkuvan elämämme ja virtaavien paikkojen vuorovaikutukselle. Kiinnostava nosto on Keräsen pohdinta kantatilatarkastelun ja rantarakentamisen vaikutuksista asutuksen muotoutumiseen maaseudulla.

Otsikon kysymykseen - missä syrjä sijaitsee? - tullaan oikeastaan vasta aivan teoksen lopussa. Vastausta kysymykseen ei kuitenkaan saada. Ei liene tarkoituskaan. Teoksen kirjoittaminen on ollut ilmeisen henkilökohtainen matka, jonka aikana on varmasti noussut esiin enemmän kysymyksiä kuin vastauksia. Tämä tekee tekstistä sekä päiväkirjamaisen että henkilökohtaisen.

Tutkijan näkökulmasta on ilahduttavaa, että politiikassa aktiivisesti mukana oleva Silja Keränen on nähnyt paljon vaivaa tutustuessaan tutkimuslähteisiin ja rakentanut niistä tulkinnoilleen laajemman viitekehyksen. Ahkerasta taustatyöstä viestii suhteellisen pitkä lähdeluettelo sekä verkon kautta tunnistettu ajankohtaiskeskustelu. Kirjoittaja on tehnyt teosta varten lisäksi 29 asiantuntijahaastattelua.

Tekstistä voi tunnistaa myös joitakin maaseutututkimuksen ajankohtaisia keskusteluja ja näkökulmia, kuten koronapandemian aiheuttaman muuttoliikkeen sekä monipaikkaisuuden. Keränen on yhteiskunnallinen vaikuttaja, ja juuri siksi tämä teos sopii hyvin Maaseutututkimus-lehdessä esiteltäväksi. Poliitikkona hän on keskustelemassa, vaikuttamassa ja päättämässä myös maaseutua koskevista linjauksista. Hän on esimerkki maaseutua koskevan tutkimustiedon käyttäjästä.

Missä syrjä sijaitsee? on ollut ilmeinen työvoitto tekijälleen, sillä kenelle tahansa näin laajan kokonaisuuden hallinta olisi suuri haaste. Materiaalia on todennäköisesti ollut yhden kirjan ylittävä määrä. Tekstiä lienee tiivistetty, mutta silti jää vaikutelma, ettei mitään lopulta haluttu jättää pois. Lopputulos on teemoiltaan ylitsepursuava. Ripaus malttia viimeistelyyn ja kerronnan virtaviivaistaminen olisivat lukukokemukseni mukaan parantaneet teosta. Maaseudun asemaa koskevasta 2020-luvun ajankohtaisesta keskustelusta laajasti kiinnostuneelle lukijalle tätä julkaisua voi kyllä suositella. 